\title{
The role of physical activity in pre-service teachers' subjective vitality
}

\author{
Abdullah Bora Özkara ${ }^{1}$, Arslan Kalkavan², Serdar Alemdağ ${ }^{1}$, Ceyhun Alemda $\breve{g}^{1 *}$, Selma Çavdar ${ }^{1}$ \\ 1 Department of Physical Education and Sports Education, Karadeniz Technical University, Turkey \\ ${ }^{2}$ Department of Physical Education and Sports Education, Recep Tayyip Erdoğan University, Turkey \\ *Corresponding Author: calemdag@ktu.edu.tr
}

\begin{abstract}
Purpose:

In the present study, subjective vitality considered to be one of the contributions provided by participation in physical activity is examined on a sample of pre-service teachers. When teachers who are important part of education system are healthy and fit, it will help to build future generations.

Material: $\quad$ The research was conducted in the city of Trabzon, located in the northeastern region of Turkey. The sample of the study is composed of 328 last grade pre-service teachers (133 women, 195 men, age: $23.14 \pm 2.62)$ studying at Karadeniz Technical University in the academic year of 2015-2016. Data was collected through Childhood and Adolescence Physical Activity Levels Questionnaire, Subjective Vitality Scale, and a personal information form asking for information about gender, doing sports as a certified sportsman/woman and department.

Results: $\quad$ The research results yielded a significant difference between subjective vitality levels of those who do sports as a certified sportsman/woman and those who do not, and between pre-service teachers of physical education and those of other departments $(p<0,01)$. There was also a positive and low-level significant relationship between subjective vitality and physical activity experiences of pre-service teachers $(r=.23 ; p<0.01)$. However, subjective vitality did not differ significantly by gender.

Conclusions: The research results seem to support other studies that reveal social and psychological contributions provided by participation in physical activity. Therefore, participation in physical activity seems to have positive effects on the subjective vitality of pre-service teachers.

Keywords: $\quad$ physical activity, pre-service teacher, subjective vitality, athlete, physical education.
\end{abstract}

\section{Introduction}

Regular and adequate physical activity in daily life is known to have a great number of physical and psychological contributions to individuals [1-4]. Especially with the changes in economic social living standards since the last quarter of the 20th century, almost every segment of society (lower, middle and upper income group) has shifted towards sedentary lifestyle. In fact, health sector that has developed rapidly with technology from this period onwards has found a solution for many infectious diseases and has now increased the hopes of people for a long and healthy life. However, effects of changing living standards have become apparent and by extension, lifestyle-related illnesses caused by inactivity have broken out $[5,6]$. Several researchers have pointed out that exercise and physical activity are effective methods in combating such problems based on sedentary lifestyle. They include physical problems as well as psychological problems such as depression, self-esteem, happiness, fitness [7-10].

University period is regarded as the last stage of education for pre-service teachers before they start their career. This period corresponds to an important time frame in which students' responsibilities begin to increase as they focus on making plans for their future and take decisions that will guide their lives. Several studies also suggest that university students should participate more in physical activities in university years. [11-16]. Okazaki et al. [17] report that 46.7 of male university students and 61.3 female university students fail to satisfy the need for daily physical activity suggested by the World Health Organization [2]. Pre-service teachers are also included (c) Abdullah Bora Özkara, Arslan Kalkavan, Serdar Alemdağ, Ceyhun Alemdağ, SelmaÇavdar, 2017 doi:10.15561/20755279.2017.0306 in the group of university students affected by physical and psychological consequences of inactive lifestyle. Teaching profession is a profession that requires, by its nature, interaction and mutual communication with a wide range of people. It may always be an advantage for teachers to communicate with school management, colleagues, education stakeholders, parents and students through a vivid and positive image. Subjective vitality defined by Ryan and Frederick [18] as a positive feeling of aliveness and energy towards the environment with which individuals interact is also a useful emotional structure for teaching profession [10, 18]. Recent research has emphasized that the concept of fitness may be indirectly related to physical activity, and individuals with a self-reported high level of physical well-being are likely to have a high level of subjective vitality [19-23]. Thus, subjective vitality appears to be a desired mood for both teachers and pre-service teachers and useful for both teachers and students during education and training activities. From this point of view, the present study attempts to investigate the role of physical activity participation in pre-service teachers' subjective vitality taking into consideration the association of physical activity with subjective vitality.

\section{Materials and Methods:}

Participants:

The present study on pre-service teachers' subjective vitality and experience of physical activity participation is a quantitative research based on descriptive survey method. The research sample consists of 328 last grade students (133 women, 195 men) studying at Karadeniz Technical University in the academic year of 2015-2016. 
Table 1. Demographics of pre-service teachers

\begin{tabular}{llll}
\hline Variables & Type & $\mathbf{n}$ & (\%) \\
\hline \multirow{2}{*}{ Gender } & Female & 134 & 40.5 \\
& Male & 197 & 59.5 \\
& Physical Education & 83 & 25.5 \\
\multirow{3}{*}{ Department } & English & 82 & 24.8 \\
& Math & 84 & 25.4 \\
& Turkish & 82 & 24.8 \\
\hline
\end{tabular}

Procedure:

Upon the receipt of all necessary permits, participants were, on the basis of volunteerism, administered the Childhood and Adolescence Physical Activity Levels Questionnaire and Subjective Vitality Scale in addition to a personal information form asking for information about gender, doing sports as a certified sportsman/woman and department. Collected data was analyzed with SPSS Statistics 20 software.

Subjective Vitality Scale

The Subjective Vitality Scale developed by Ryan and Frederick [18] measures an individual's level of vitality, aliveness and alertness. The scale was adapted into Turkish by Uysal, Sarıçam and Akın [24]. It consists of 7 items and uses a 7-point Likert scale (ranging from $1=$ strongly disagree to $7=$ strongly agree). The total score on this self-report scale indicates the level of subjective vitality. The internal consistency coefficient is calculated to be .84 [24].

Childhood and Adolescence Physical Activity Levels Questionnaire

The Childhood and Adolescence Physical Activity Levels Questionnaire developed by Massie and adapted into Turkish by Ayhan and Saygin [25] determines an individual's experiences of physical education and physical activity throughout their years of primary school, middle school, high school and university. [25]. Total score is calculated by the mean score in all periods on this 5-point Likert scale. The internal consistency coefficient is .95.

\section{Results}

According to the results of the Mann-Whitney U test conducted to determine pre-service teachers' participation in physical activity by the variable of gender, male preservices teachers had a significantly higher score than female pre-services teachers ( $U=11172.500, p<0.05$ ).

According to the results of the Mann-Whitney $U$ test conducted to analyze pre-service teachers' scores on the Subjective Vitality Scale by gender, no significant difference was found between male and female preservice teachers in terms of their scores on the Subjective Vitality Scale ( $U=12713.00, \mathrm{p}>0.05)$.

According to the results of the Mann-Whitney $U$ test analyzing pre-service teachers' subjective vitality scores by the variable of sports participation as a certified sportsman/woman, pre-service teachers participating in sports as a certified sportsman/woman had a significantly higher score of subjective vitality compared to those who did not participate in sports $(\mathrm{U}=6222.500 \mathrm{p}<0.05)$.

According to the results of one-way ANOVA conducted to evaluate pre-service teachers' scores of participations in physical activity by the variable of department, the participation scores differed significantly between departments ](Physical Education, English, Math and Turkish) $[\mathrm{F}(3,562)=76,256, \mathrm{p}<0.01)$. According to the results of the Tukey HSD test to find out between which groups there were differences, pre-service teachers of physical education $(\chi=17.38)$ participated in sports in a significantly higher rate compared to pre-service teachers of other departments, and pre-service teachers of Turkish department $(\chi=13.23)$ participated in sports in a significantly higher rate compared to pre-service teachers of Math department.

According to the results of Kruskal-Wallis Test performed to evaluate pre-service teachers' scores of subjective vitality by the variable of department, the subjective vitality scores differed significantly between departments (Physical Education, English, Math and Turkish) in favor of pre-service teachers of physical education $\left(\chi^{2}(\mathrm{sd}=3, \mathrm{n}=331)=80,92, \mathrm{p}<0\right)$.

According to the results of the correlation test conducted to examine the relationship between pre-

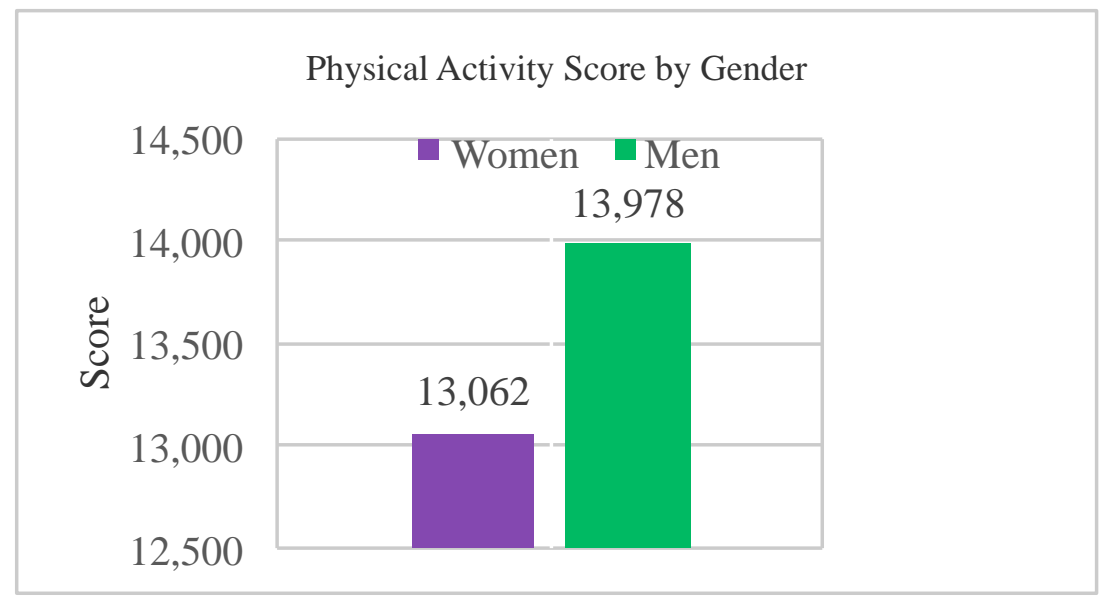

Diagram 1. Physical activity scores of pre-service teachers by gender. 


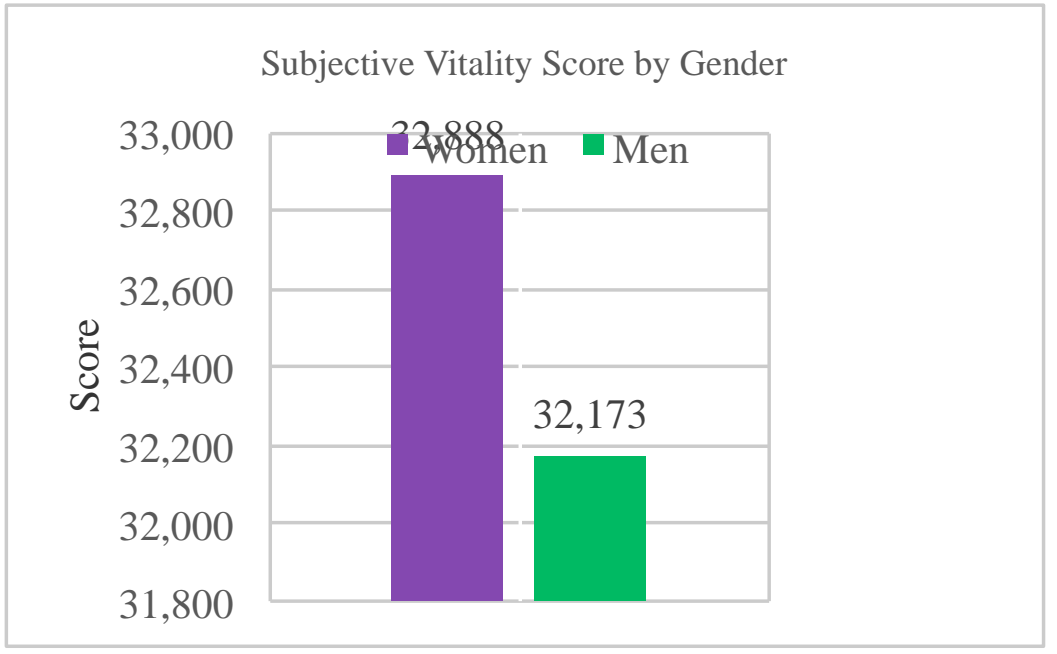

Diagram 2. Subjective vitality scores of pre-service teachers by gender.

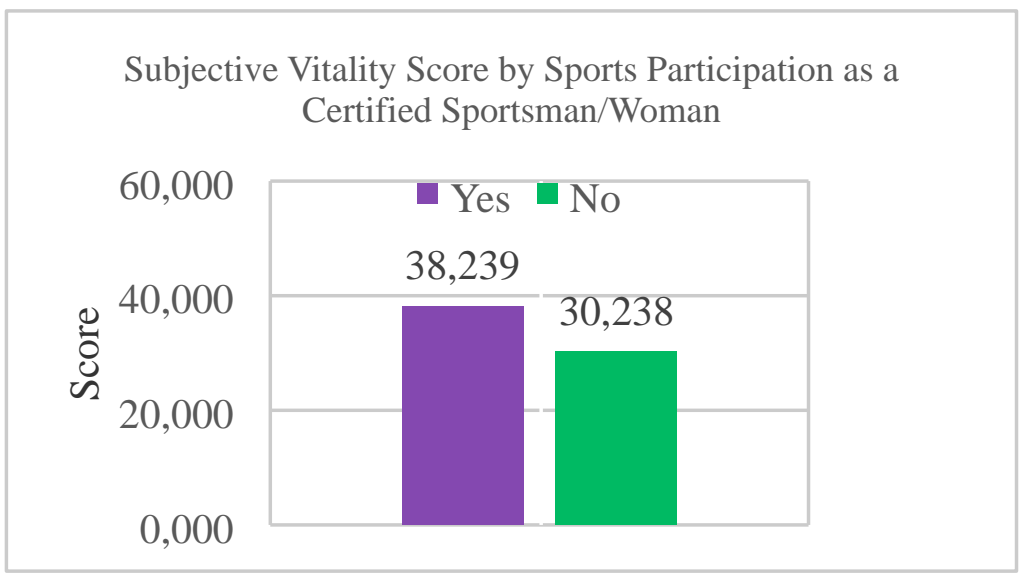

Diagram 3. Subjective vitality scores of pre-service teachers by sports participation as a certified sportsman/woman

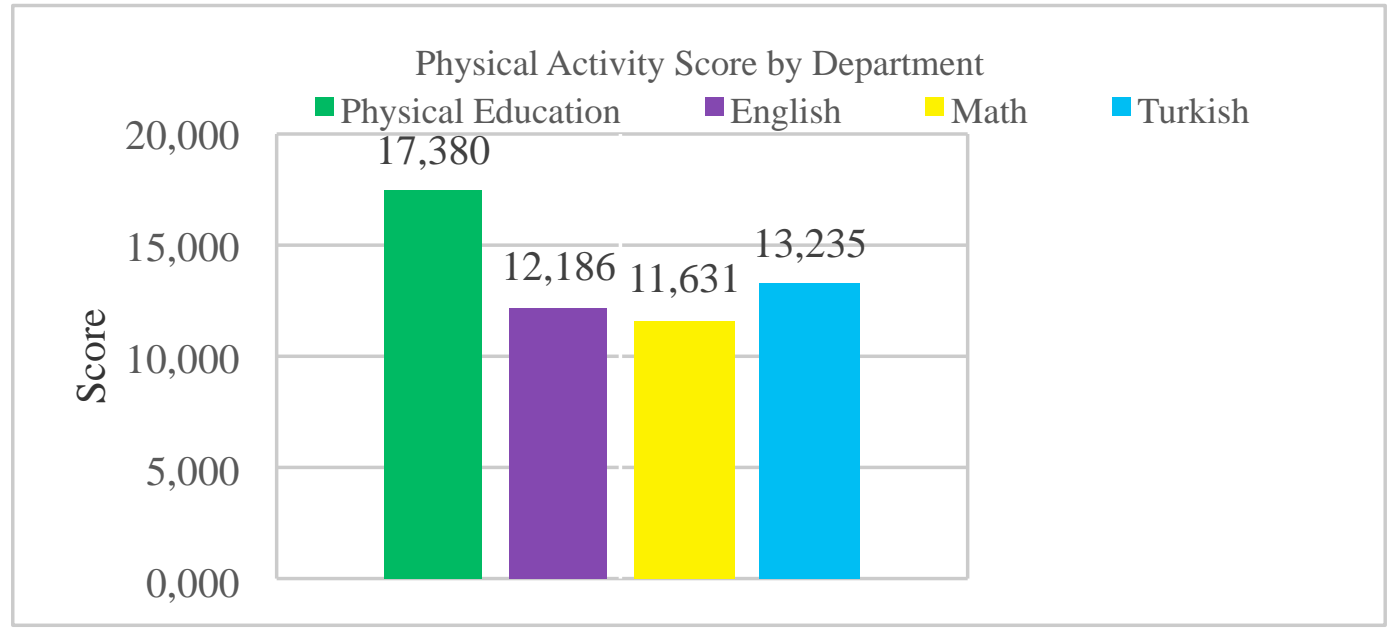

Diagram 4. Scores of participations in physical activity by department

Table 2. Relationship between physical activity and subjective vitality

\begin{tabular}{llll}
\hline & \multicolumn{3}{c}{ Subjective Vitality } \\
\hline & $\mathrm{n}$ & $\mathrm{r}$ & $\mathrm{p}$ \\
Physical Activity & 328 & 0.23 & 0.01 \\
\hline
\end{tabular}




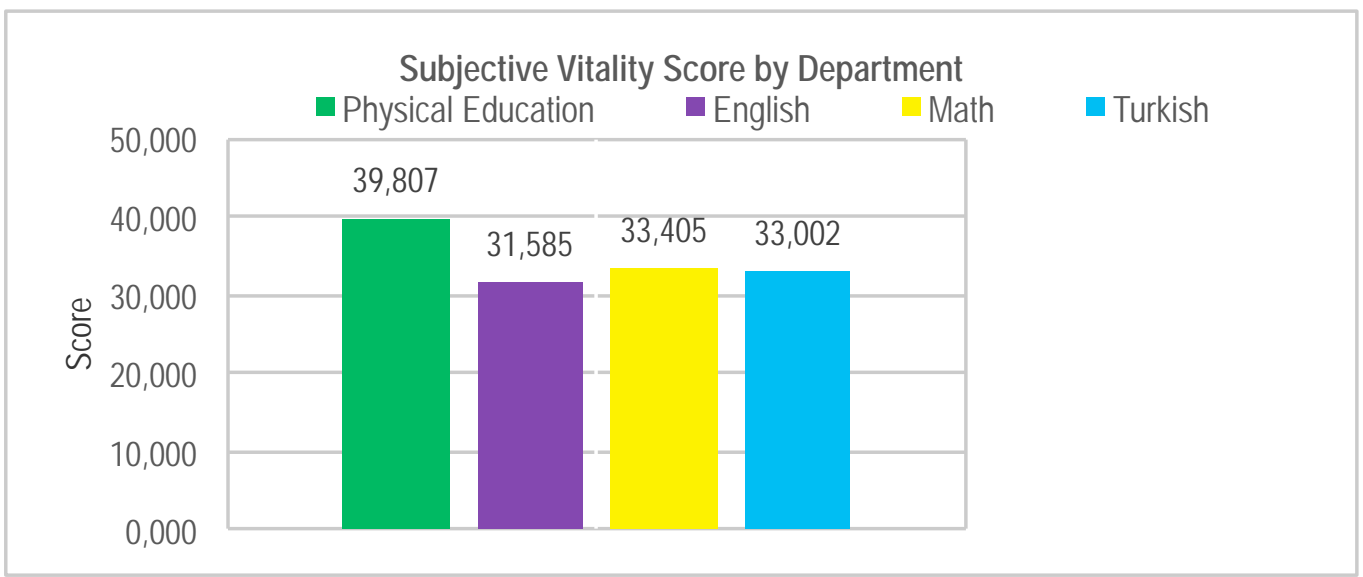

Diagram $\mathbf{5}$. Subjective vitality scores by department

service teachers' experiences of participation in physical activity and their subjective vitality, there is a low, positive and significant relationship between experience of physical activity participation and subjective vitality $(\mathrm{r}=.23 ; \mathrm{p}<0.01)$.

\section{Discussion}

The present study examining the role of physical activity in pre-service teachers' subjective vitality found out that the subjective vitality scores of pre-service teachers participating in sports a certified sportsman/ woman were significantly higher than the scores of other pre-service teachers. Pre-service teachers studying at physical education department had a higher score on the Subjective Vitality Scale than those studying at other departments. Another significant difference was that male pre-service teachers had a higher score on the Childhood and Adolescence Physical Activity Levels Questionnaire. According to the results of the regression analysis conducted in order to determine the role of physical activity in pre-service teachers' subjective vitality, physical activity has a low-level and significantly positive role for the relevant sample group. However, pre-service teachers' subjective vitality did not differ significantly by gender. Vlachopoulos [26] investigated the role of physical education class in the subjective vitality of middle school students and pointed out that particular importance had to be given to the contributions of physical education course [26][25]. Several studies have indicated that physical activity and participation in physical education and sport activities have various psychological and physical contributions [26 - 31]. Thus, the results of the presents study seem to be in parallel with those of such studies. Studies on the predictors of subjective vitality examine such variables as psychological well-being [32], social autonomy [33], personality and healthy life [18], personal well-being [34] and subjective happiness [35]. Experiences of participation in physical education and physical activity are in a positive relationship with respect to individuals' benefiting from the positive contributions of these concepts. A longitudinal study conducted by Kinnafick et al. [33] in the framework of the theory of basic needs, and in a descriptive research performed by Fini et al. [32] in the framework of the theory of selfdetermination have argued that physical activity behaviors have an instrumental role in helping individuals feel vital [32, 33]. This supports the high level of subjective vitality scores of pre-service teachers participating in any sports activity as a certified sportsman/woman, which is one of the results of the present study. It is one of the most important expectations of each period in education life that students acquire the achievements of that turn at every stage of education. It is of key importance that teachers who always accompany students on this journey and help them get the best out of this process feel vital and alive in order to facilitate the development of students.

\section{Conclusion}

Given that physical activity has a positive role in individuals' levels of subjective vitality, participation in physical activities seems to be a helpful behavior for pre-service teachers. Thus, when pre-service teachers' participation in physical activity is turned into behavior, it will later contribute to the sustainability of physical activity behaviors in their professional careers. From this point of view, it may be suggested that institutions that determine education policies should support the participation of students and teachers in physical activities. This research that examines the role of physical activity in pre-service teachers' subjective vitality may be developed in different sample groups, for example by studying the physical activity and subjective vitality of in-service teachers.

\section{Conflict of interests}

The authors declare that there is no conflict of interests. 


\section{References}

1. Duncan SC, Duncan TE, Strycker LA, Chaumeton NR. A cohort-sequential latent growth model of physical activity from ages 12 to 17 years. Ann Behav Med. 2007;33(1):80-9.

2. WHO. Global Recommendations on Physical Activity for Health. Geneva; 2010.

3. Warburton DER, Nicol CW, Bredin SSD. Health benefits of physical activity: the evidence. CMAJ. 2006;174(6):801-9.

4. Kolumbet AN, Dudorova LY. Correction of physical education program for technical higher educational establishment girlstudents on the base of their health indicators. Phys Educ Students. 2016;20(6):18-25.

5. Katzmarzyk PT, Mason C. The Physical Activity Transition. J Phys Act Heal, 2009;6(3):269-80.

6. Cekin R. Psychological Benefits of Regular Physical Activity: Evidence from Emerging Adults. Univers J Educ Res. 2015;3(10):710-7.

7. Özkara AB, Kalkavan A, Çavdar S. Examination of the Life Satisfactions Levels of Students Receiving Education in Sports Sciences. Int J Sci Cult Sport. 2015;(3):100-116.

8. Sallis JF, Owen N. Physical Activity and Behavioral Medicine. London: Sage Publications; 1999.

9. Garcia JM, Castillo I, Queralt A. Leisure-time physical activity and psychological well-being in university students. Psychol Rep. 2011;109(2):453-60.

10.Yazıcı ÖF. Beden Eğitimi Öğretmeni Adaylarının Mutluluk ve Zindelik Düzeylerinin Incelenmesi [Examination of Happiness and Fitness Levels of Physical Education Teacher Candidates]. Karadeniz Teknik Üniversitesi: Eğitim Bilimleri Enstitüsü; 2015. (in Turkish)

11.Koca C, Aşçı HF, Demirhan G. Attitudes Toward Physical Education And Class Preferences Of Turkish Adolescents In Terms Of School Gender Composition. Adolescence. 2005;40(158).

12.Ince ML, Ebem Z. Role of Exercise Stages in Self-Reported Health-Promoting Behaviors of a Group of Turkish Adolescents at Transition to University. Percept Mot Skills. 2009;108(2):399-404.

13.Cengiz C, Ínce ML, Çiçek Ş. Exercise Stages of Change in Turkish University Students by Sex, Residence, and Department. Percept Mot Skills. 2009;108(2):411-21.

14.Öncü E, Cihan H. The Development of Physical Education Lesson Attitude Scale for Preservice Classroom Teachers. Dicle Univ J Fac Educ Ziya Gokalp. 2012;18(31):31-47.

15.Alemdağ S, Öncü E, Sakallığlu F. Preservice Classroom Teachers' Attitude And Self-Efficacy Towards Physical Education Course. Abant İzet Baysal Üniversitesi Eğitim Fakültesi Derg. 2014;14(2):45-60.

16.Kaya S, Gürbüz B. An Examination of University Students' Attitudes Towards Leisure Activities. Pamukkale J Sport Sci. 2015;6(3):46-60.

17.Okazaki K, Okano S, Haga S, Seki A, Suzuki H, Takahashi K. One-year outcome of an interactive internet-based physical activity intervention among university students. Int $\mathrm{J}$ Med Inform. 2014;83(5):354-60.

18.Ryan RM, Frederick C. On Energy, Personality, and Health: Subjective Vitality as a Dynamic Reflection of Well-Being. $J$ Pers. 1997;65(3):529-65.

19.Moliver N. Psychological wellness, physical wellness, and subjective vitality in long-term yoginis over 45 . Dissertation Abstracts International: Section B: The Sciences and Engineering. 2010.
20.Vlachopoulos SP, Karavani E. Psychological needs and subjective vitality in exercise: a cross-gender situational test of the needs universality hypothesis. Hell J Psychol. 2009;6:207-22.

21.Costa D, Vieira R, Avellar De Aquino TA. Subjective vitality, meaning in life and religiosity in older people: a correlational study. Temas psicol. 2016;24(2):483-494. doi:9788/ TP2016.2-05Pt

22.Li C-H. Predicting subjective vitality and performance in sports: the role of passion and achievement goals. Perceptual and Motor Skills. 2010;110(3C):1029-47.

23. Wong $\mathrm{W}$, Li Y, Sun X, Xu H. Subjective Vitality ScaleChinese Version. PsycTESTS; 2014.

24.Uysal R, Sarıçam H, Akın A. The Psychometric Properties of Turkish Version of Subjective Vitality Scale. Sosyal Bilimler Enstitüsü Dergisi, 2014;4(33):136-46.

25.Ayhan YF, Saygın Ö. Physical Activity Experiences during Childhood and Adolescence and Examination of Physical Composition Levels and Body Composition in Adulthood. Muğla Sitkı Koçman University; 2014.

26.Vlachopoulos SP. The role of self-determination theory variables in predicting middle school students' subjective vitality in physical education. Hell J Psychol. 2012;9(2):179204.

27.Taylor IM, Lonsdale C. Cultural differences in the relationships among autonomy support, psychological need satisfaction, subjective vitality, and effort in British and Chinese physical education. J Sport Exerc Psychol. 2010 Oct;32(5):655-73.

28. Younes MS, Salama-Younes M. Positive Mental Health, Subjective Vitality and Satisfaction with Life for French Physical Education Students. World J Sport Sci. 2011;4(2011):90-7.

29.Ommundsen Y, Lemyre PN, Abrahamsen F, Roberts GC. Motivational climate, need satisfaction, regulation of motivation and subjective vitality. A study of young soccer players. Int J Sport Psychol. 2010;41(3):216-42.

30.Dwyer T, Coonan W, Leitch DR, Hetzel BS, Baghurst RA. An Investigation of the Effects of Daily Physical Activity on the Health of Primary School Students in South Australia. Int J Epidemiol. 1983;12(3):308-13.

31.Hilland TA, Stratton G, Vinson D, Fairclough S. The Physical Education Predisposition Scale: Preliminary development and validation. J Sports Sci. 2009;27(14):1555-63.

32.Fini AAS, Kavousian J, Beigy A, Emami M. Subjective vitality and its anticipating variables on students. Procedia Soc Behav Sci. 2010;5(11):150-6.

33.Kinnafick F-E, Thøgersen-Ntoumani C, Duda JL, Taylor I. Sources of autonomy support, subjective vitality and physical activity behaviour associated with participation in a lunchtime walking intervention for physically inactive adults. Psychol Sport Exerc. 2014;15(2):190-7.

34.Sylvester BD, Lubans DR, Eather N, Standage M, Wolf SA, McEwan D, vd. Effects of Variety Support on ExerciseRelated Well-Being. Appl Psychol Heal Well-Being. 2016;8(2):213-31.

35.Akın A. The Relationships Between Internet Addiction, Subjective Vitality, and Subjective Happiness. Cyberpsychology, Behav Soc Netw. 2012;15(8):404-10. 
Information about the authors:

Abdullah Bora Ozkara; http://orcid.org/0000-0003-1688-3410; boraozkara@ktu.edu.tr; Karadeniz Technical University, Faculty of Sports Sciences; 61080, Trabzon, Turkey.

Arslan Kalkavan; http://orcid.org/0000-0001-9439-4976; arslan.kalkavan@erdogan.edu.tr; Recep Tayyip Erdoğan University, Faculty of Sports Sciences; 53100 Rize, Turkey.

Serdar Alemdag; http://orcid.org/0000-0002-6478-3361; serdar.alemdag@ktu.edu.tr; Karadeniz Technical University, Faculty of Sports Sciences; 61080, Trabzon, Turkey.

Ceyhun Alemdag; http://orcid.org/0000-0001-9892-820X; calemdag@ktu.edu.tr; Karadeniz Technical University, Faculty of Sports Sciences; 61080, Trabzon, Turkey.

Selma Çavdar; http://orcid.org/0000-0001-8326-9942; selmasoyyigit@ktu.edu.tr; Karadeniz Technical University, Faculty of Sports Sciences; 61080, Trabzon, Turkey.

Cite this article as: Özkara Abdullah Bora, Kalkavan Arslan, Alemdă̆ Serdar, Alemdağ Ceyhun, Çavdar Selma. The role of physical activity in pre-service teachers' subjective vitality. Physical education of students, 2017;21(3):134-139. doi:10.15561/20755279.2017.0306

The electronic version of this article is the complete one and can be found online at: http://www.sportedu.org.ua/index.php/PES/issue/archive

This is an Open Access article distributed under the terms of the Creative Commons Attribution License, which permits unrestricted use, distribution, and reproduction in any medium, provided the original work is properly cited (http://creativecommons.org/licenses/by/4.0/deed.en)

Received: 20.04.2017

Accepted: 29.04.2017; Published: 10.05.2017 